\title{
Multi Objective Optimization on Machinability Aspects of Dry Hard Turning of EN31 Alloy Steel using Coated Inserts
}

\author{
T. Gunasekar*, S. Thirunavukkarasu, B. Abinesh, M. Arunpragash and Ashwin Prabhakar \\ Sri Krishna College of Engineering and Technology, Coimbatore-641008, Tamil Nadu, India; guna.me93@gmail. \\ com, thirunavu1996@gmail.com, abiabinesh@ymail.com, m.arunpragash@gmail.com, \\ ashwinakash1999@gmail.com
}

\begin{abstract}
Objective: In this work, the design parameters that significantly affect the machinability of EN31 alloy steel using coated carbides were analysed and optimized using multi response methodology. Methods/Statistical Analysis: The EN31 steel is machined in the dry cutting environment using the coated carbide insert and their evaluation is studied. The experiments were conducted with three significant parameters namely cutting speed, feed rate and depth of cut. These parameters are optimized using Taguchi based grey relational analysis and their effects of parameters on surface roughness, interface temperature and flank wear were examined. Findings: The result reveals that all three input variables have influence over surface roughness, interface temperature and flank wear. ANOVA indicates that the output response is greatly influenced by cutting speed followed by feed and depth of cut. The results at optimum condition were predicted and it is found to be closer to the experimental results. From the analysis, it has been found that the coated carbide exceeds the performance compared to the uncoated carbides. Application/Improvements: The optimum parameters obtained from this experiment are effective in improving the machinability of EN31 alloy steel in the industry that minimizes cost and time.
\end{abstract}

Keywords: Alloy Steel, ANOVA, Grey Relational Analysis, Hard Turning, Machinability

\section{Introduction}

In recent days, various manufacturing industries works in the machining of hardened steel toward the improvement of product quality. To obtain desired outputs the manufacturers are focusing continuously to obtain the finished products with good quality reduced cost and less time by optimizing the machining parameters.

The conventional grinding operations have been replaced by an evolving technology called hard turning that should be implemented to achieve the good surface finish. Hard turning is the machining of the hardened materials in which the hardness lies between 45 and 65 $\mathrm{HRC}^{1-4}$. In ${ }^{5}$ investigated the machinability of hardened steel during both hard and soft turning using ceramic tools mixed with $\mathrm{TiC}$ and alumina. He observed the cutting force and the interfacial temperature to be high and surface roughness to be low for harder work piece. Further the surface roughness gets influenced by the feed rate whereas the interface temperature is influenced with cutting speed and depth of cut. The depth of cut followed by the feed value affects the tangential and feed cutting forces. $\mathrm{In}^{6}$ conducted an experiment in multi-layer coating on cemented carbide using the chemical vapour deposition and observed abrasive wear mechanism in all conditions for AISI 4340. The surface roughness is minimized with the low feed rate and high cutting speed. $\operatorname{In}^{7}$ concluded from his experiment that both chipping and 
abrasive wear is observed while hard turning of AISI 4340 steel with the multilayer coated carbide insert under the dry cutting environment. The surface quality is better for the insert coated with multilayer TiN when compared to the cylindrical grinding. Also he suggested that the tool wear and surface roughness is being affected with the cutting speed and the feed. In ${ }^{8}$ found that the tool life of coated carbide insert with CVD is 15 times higher than that of uncoated carbide inserts for machining of AISI D2 steel in dry cutting environment. The chip volume is 26.14 times higher for the coated carbide when compared to uncoated carbide that could be preferred for high material removal rate. $\mathrm{In}^{2}$ investigated the cutting parameter and coating effect with single layered TiAlN and multilayer $\mathrm{TiCN} / \mathrm{Al}_{2} \mathrm{O}_{3} / \mathrm{TiN}$ using $\mathrm{CVD}$ technique during hard turning of AISI 4340 hardened steel. They concluded that when compared to single layer coated tool the interface temperature is high for the multilayer coated tool using CVD. The depth of cut has a great impact on interface temperature for coated carbide tools. The same authors on reviewing many articles concluded that various researches have been conducted in the machinability aspects with different work and tool materials under various conditions whereas the influence of machining parameters on quality have not been studied ${ }^{10}$. $\operatorname{In}^{11}$ investigated the effect of power consumption and surface roughness generated in hard turning of EN31 alloy steel under different parameters with tungsten carbide tool coated with $\mathrm{TiN} / \mathrm{Al}_{2} \mathrm{O}_{3} / \mathrm{TiCN}$. They found that the power consumption and the surface roughness is being affected with all the input parameters such as cutting speed, feed and depth of cut. Finally they concluded that the machining parameters should be optimized using the design of experiments to obtain good surface finish with less power consumption.

In ${ }^{12}$ conducted an experiment in turning of EN 31 steel and investigated how the surface roughness is affected with the machining parameters. They analyzed that the surface roughness is affected significantly by speed, feed and depth of cut, tool nose radius and lubricants.

$\mathrm{In}^{\frac{13}{3}}$ examined the wear and turning characteristics in hardened steel coated with multilayered cemented carbide and cermet. The life of the cermet tool was good at lower cutting depth and for the larger cutting depth it decreases due to chipping. The abrasive wear and crater wear due to diffusion is observed in the coated tool. The surface quality of machined surface is low for the cermet tool compared to the coated carbide tool. In conducted an experiment with CVD coated tungsten carbide tools that has intermediate layer of $\mathrm{Al}_{2} \mathrm{O}_{3}$ and PCBN tools for the hard turning of D2 tool. It is found that the tool with coated carbide performs better compared to PCBN within a certain cutting speed and this is due to the formation of tribo-film on the surface. $\operatorname{In}^{14}$ also performed an experiment with same steel using different cutting tool materials namely TiN, PCBN and mixed aluminium ceramic. It is found that mixed alumina ceramic tool performs better under different machinability criteria in comparison with other cutting tools. $\mathrm{In}^{15}$ performed an experiment in turning of hard $42 \mathrm{CrMo} 4$ steel with $\mathrm{Al}_{2} \mathrm{O}_{3} / \mathrm{TiC}$ mixed cutting tool and examined the surface roughness under different conditions. From the results it has been found that feed rate plays a dominant role in affecting the surface roughness and a good correlation is observed between actual and the predicted values. In ${ }^{16}$ carried out research with the $\mathrm{TiC}$ based cermets and it has been found that Mo is considered as good binding material due to its good wettability property compared to Ni binder as it has low wettability property.

From the literature review it reveals that the research work is carried on dry hard machining of AISI4340 steel and D2 steel whereas very limited work is found for EN31 steel. Further comparative analyses of EN31 steel using multilayered carbide inserts has not been done.

The objective of our research is based on analysing the machining parameters while hard turning of EN31 steel with multilayer coated carbide in the dry cutting environment. The hard turning operations were carried out as per the design of experiments using Taguchi's L9 orthogonal array. Analysis of variance is also conducted to identify the influencing input parameters for the output response. The interactions between these parameters were fitted with the regression model. Also, the various output responses were optimized using multi-response methodology like Grey Relational Analysis.

\section{Experimental Details}

\subsection{Workpiece Material}

EN-31 equivalent to AISI 52100 (high strength) steel test samples of dimensions $\varnothing 63 \times 2000 \mathrm{~mm}$ is used for the experiment. EN-31 steel has a greater hardness for which it is quite difficult to machine it. This material has wider applicability in the industry because of its greater wear resistance and hardness. 
Figure 1 shows the EN31 alloy steel used for the experiment and Table 1 shows the chemical composition of EN31 alloy steel.

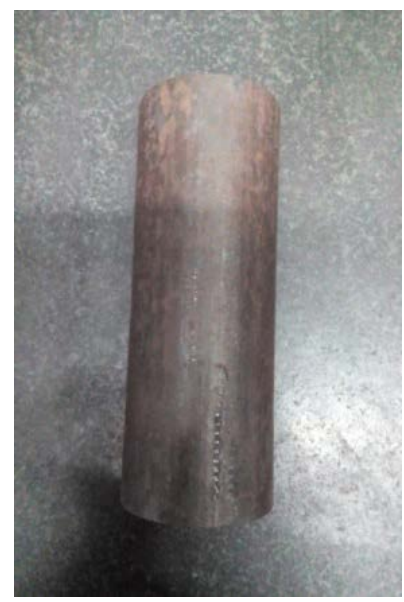

Figure 1. Workpiece

\subsection{Cutting Tools}

In the present work, the carbide used is Tungsten, Cobalt based, designated by TNMG 120408. The insert is triangular in shape with the chip breaker geometry that is mounted on the tool holder. The tool holder has the clearance angle of $0^{\circ}$, entering angle of $75^{\circ}$, back and side rake angle of $-6^{\circ}$, point angle of $90^{\circ}$ and nose radius of $0.8 \mathrm{~mm}$.

The ceramic particles with metallic binders of TiN/ TiCN/TiN were used as coating material for carbide insert by Physical Vapour Deposition technique as shown in Figure 2. The inner and the outer most layers is given with the Titanium nitride coatings and the intermediate layer with the Titanium carbonitride.

\subsection{Machine Tool and Measuring Instruments}

Figure 3 shows the turning operation of EN31 steel. The surface roughness tester is used to measure the roughness of the surface and the infrared thermometer measures the interface temperature. By analysing the SEM image the insert flank wear is found.
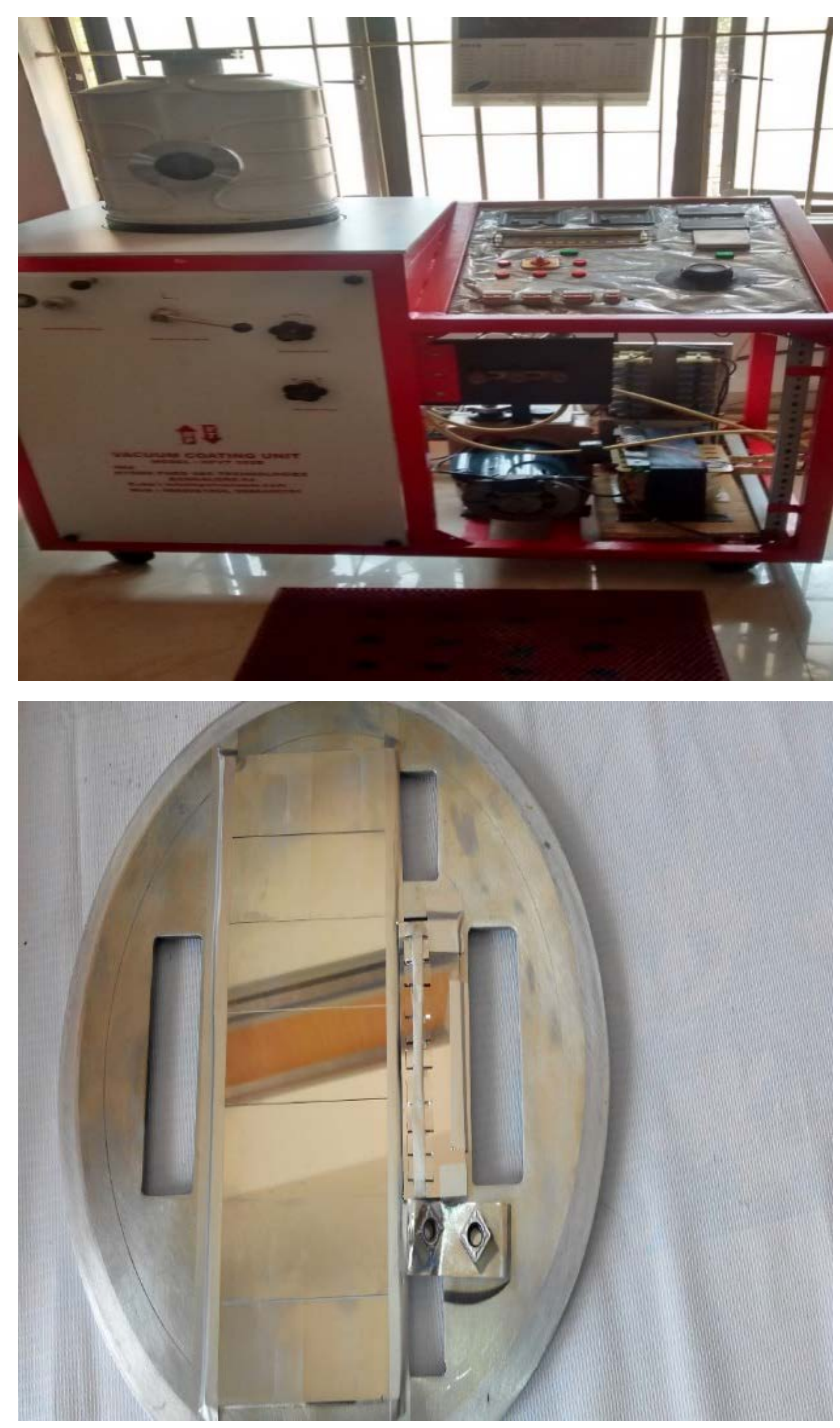

Figure 2. Thermal evaporation setup and coated insert.

\subsection{Experimental Layout}

During hard turning the three input parameters such as cutting speed, feed rate and depth of cut were varied and the output response like surface roughness, interfacial temperature and flank wear were analyzed. The experiments were planned as per the design of experiments using Taguchi's L9 orthogonal array. The input factors and levels for the experiment is tabulated in Table 2.

Table 1. Chemical composition of EN31 alloy steel

\begin{tabular}{|l|l|l|l|l|l|l|l|l|}
\hline Element & $\mathrm{Si}$ & $\mathrm{C}$ & $\mathrm{S}$ & $\mathrm{Mn}$ & $\mathrm{P}$ & $\mathrm{Ni}$ & $\mathrm{Cr}$ & $\mathrm{Mo}$ \\
\hline $\begin{array}{l}\text { Chemical } \\
\text { composition }\end{array}$ & $0.25 \%$ & $1.08 \%$ & $0.015 \%$ & $0.53 \%$ & $0.022 \%$ & $0.33 \%$ & $1.46 \%$ & $0.06 \%$ \\
\hline
\end{tabular}


Table 2. Input factors and levels

\begin{tabular}{|l|l|l|l|l|}
\hline Factors & $\begin{array}{l}\text { Process } \\
\text { parameters }\end{array}$ & Level 1 & Level 2 & Level 3 \\
\hline A & $\begin{array}{l}\text { Cutting Speed } \\
(\mathrm{m} / \mathrm{min})\end{array}$ & 100 & 150 & 200 \\
\hline B & Feed $(\mathrm{mm} / \mathrm{rev})$ & 0.1 & 0.2 & 0.3 \\
\hline C & $\begin{array}{l}\text { Depth of Cut } \\
(\mathrm{mm})\end{array}$ & 0.1 & 0.5 & 1.0 \\
\hline
\end{tabular}

Table 3. Experimental results for coated carbide

\begin{tabular}{|l|l|l|l|l|l|l|}
\hline $\begin{array}{l}\text { Experimental } \\
\text { run }\end{array}$ & $\begin{array}{l}\text { Cutting } \\
\text { Speed }(\mathrm{m} / \\
\mathrm{min})\end{array}$ & $\begin{array}{l}\text { Feed } \\
(\mathrm{mm} / \\
\mathrm{rev})\end{array}$ & $\begin{array}{l}\text { Depth } \\
\text { of Cut } \\
(\mathrm{mm})\end{array}$ & $\begin{array}{l}\text { Surface } \\
\text { Roughness } \\
(\mu \mathrm{m})\end{array}$ & $\begin{array}{l}\text { Interface } \\
\text { Temperature } \\
\left({ }^{\circ} \mathrm{C}\right)\end{array}$ & $\begin{array}{l}\text { Flank Wear } \\
(\mathrm{mm})\end{array}$ \\
\hline 1 & 100 & 0.1 & 0.1 & 0.56 & 152 & 0.21 \\
\hline 2 & 100 & 0.2 & 0.5 & 0.79 & 155 & 0.32 \\
\hline 3 & 100 & 0.3 & 1.0 & 0.81 & 163 & 0.25 \\
\hline 4 & 150 & 0.1 & 0.5 & 0.42 & 170 & 0.41 \\
\hline 5 & 150 & 0.2 & 1.0 & 0.53 & 177 & 0.39 \\
\hline 6 & 150 & 0.3 & 0.1 & 0.64 & 165 & 0.25 \\
\hline 7 & 200 & 0.1 & 1.0 & 0.36 & 205 & 0.49 \\
\hline 8 & 200 & 0.2 & 0.1 & 0.49 & 191 & 0.43 \\
\hline 9 & 200 & 0.3 & 0.5 & 0.68 & 195 & 0.36 \\
\hline
\end{tabular}

Table 4. ANOVA of surface roughness for coated carbide

\begin{tabular}{|l|l|l|l|l|l|l|}
\hline Source & DF & SS & MS & F & P & Remarks \\
\hline $\begin{array}{l}\text { Cutting } \\
\text { speed }\end{array}$ & 2 & 17.4204 & 8.7102 & 37.81 & 0.026 & Significant \\
\hline Feed & 2 & 26.0751 & 13.0376 & 56.60 & 0.017 & Significant \\
\hline $\begin{array}{l}\text { Depth of } \\
\text { cut }\end{array}$ & 2 & 1.8633 & 0.9316 & 4.04 & 0.198 & Insignificant \\
\hline Error & 2 & 0.4607 & 0.2304 & & & \\
\hline Total & 8 & 45.8196 & & & & \\
\hline $\begin{array}{l}\text { S }= \\
0.479963\end{array}$ & $\begin{array}{l}\text { R-sq }= \\
98.99 \%\end{array}$ & & $\begin{array}{l}\text { R-sq (adj) } \\
=95.98 \%\end{array}$ & & & \\
\hline
\end{tabular}

Table 5. ANOVA of interfacial temperature for coated carbide

\begin{tabular}{|l|l|l|l|l|l|l|}
\hline Source & DF & SS & MS & F & P & Remarks \\
\hline Cutting speed & 2 & 6.06476 & 3.03238 & 4335.68 & 0.000 & Significant \\
\hline Feed & 2 & 0.00183 & 0.00091 & 1.31 & 0.433 & Insignificant \\
\hline Depth of cut & 2 & 0.57968 & 0.28984 & 414.41 & 0.002 & Significant \\
\hline Error & 2 & 0.00140 & 0.00070 & & & \\
\hline Total & 8 & 6.64766 & & & & \\
\hline S =0.0264462 & \multicolumn{7}{|l|}{ R-sq =99.98\% } & R-sq (adj) $=99.92 \%$ & & \\
\hline
\end{tabular}


Table 6. ANOVA of insert wear for coated carbide

\begin{tabular}{|l|l|l|l|l|l|l|}
\hline Source & DF & SS & MS & F & P & Remarks \\
\hline $\begin{array}{l}\text { Cutting } \\
\text { speed }\end{array}$ & 2 & 28.787 & 14.393 & 13.39 & 0.070 & Insignificant \\
\hline Feed & 2 & 10.132 & 5.066 & 4.71 & 0.175 & Insignificant \\
\hline $\begin{array}{l}\text { Depth of } \\
\text { cut }\end{array}$ & 2 & 9.281 & 4.640 & 4.32 & 0.188 & Insignificant \\
\hline Error & 2 & 2.150 & 1.075 & & & \\
\hline Total & 8 & 50.349 & & & & \\
\hline $\begin{array}{l}\text { S }= \\
1.03688\end{array}$ & R-sq $=95.73 \%$ & $\begin{array}{l}\text { R-sq (adj) } \\
82.92 \%\end{array}$ & & \\
\hline
\end{tabular}

Table 7. Normalized values of output responses and quality loss function

\begin{tabular}{|c|c|c|c|c|c|c|}
\hline \multirow[t]{2}{*}{ Run } & \multicolumn{3}{|c|}{ Normalized Values } & \multicolumn{3}{|c|}{$\begin{array}{l}\text { Quality Loss } \\
\text { Function }\end{array}$} \\
\hline & $\mathrm{Ra}$ & $\mathrm{T}$ & $\mathrm{VBc}$ & $\mathrm{Ra}$ & $\mathrm{T}$ & VBc \\
\hline 1 & 0.555 & 1 & 1 & 0.444 & 0 & 0 \\
\hline 2 & 0.044 & 0.943 & 0.607 & 0.955 & 0.057 & 0.393 \\
\hline 3 & 0 & 0.792 & 0.857 & 1 & 0.207 & 0.143 \\
\hline 4 & 0.867 & 0.660 & 0.286 & 0.133 & 0.340 & 0.714 \\
\hline 5 & $\begin{array}{l}0.622 \\
0.528 \\
\end{array}$ & & $\begin{array}{l}0.357 \\
0.378 \\
\end{array}$ & & 0.472 & 0.643 \\
\hline 6 & 0.378 & 0.755 & 0.857 & 0.622 & 0.245 & 0.143 \\
\hline 7 & 1 & 0 & 0 & 0 & 1 & 1 \\
\hline 8 & 0.711 & 0.264 & 0.214 & 0.289 & 0.735 & 0.786 \\
\hline 9 & 0.289 & 0.189 & 0.464 & 0.711 & 0.811 & 0.536 \\
\hline
\end{tabular}

Table 8. Individual grey relational coefficient and grey relational grade

\begin{tabular}{|l|l|l|l|l|l|}
\hline \multirow{2}{*}{ Run } & \multicolumn{3}{|l|}{ Grey Relation Coefficient } & Grey \\
\cline { 2 - 6 } & Ra & T & VBc & $\begin{array}{l}\text { Relational } \\
\text { Grade }\end{array}$ & Rank \\
\hline 1 & 0.529 & 1 & 1 & 0.843 & 1 \\
\hline 2 & 0.343 & 0.898 & 0.56 & 0.601 & 4 \\
\hline 3 & 0.333 & 0.707 & 0.778 & 0.606 & 3 \\
\hline 4 & 0.789 & 0.595 & 0.412 & 0.599 & 5 \\
\hline 5 & 0.570 & 0.514 & 0.437 & 0.507 & 7 \\
\hline 6 & 0.445 & 0.671 & 0.778 & 0.631 & 2 \\
\hline 7 & 1 & 0.333 & 0.333 & 0.555 & 6 \\
\hline 8 & 0.634 & 0.404 & 0.389 & 0.476 & 8 \\
\hline 9 & 0.413 & 0.381 & 0.483 & 0.426 & 9 \\
\hline
\end{tabular}


Table 9. ANOVA of GRG at significance level of 5\%

\begin{tabular}{|l|l|l|l|l|l|}
\hline Source & DF & SS & MS & F & P \\
\hline Cutting speed & 2 & 0.058669 & 0.029334 & 25.91 & 0.037 \\
\hline Feed & 2 & 0.032041 & 0.016020 & 14.15 & 0.066 \\
\hline Depth of cut & 2 & 0.020696 & 0.010348 & 9.14 & 0.099 \\
\hline Error & 2 & 0.002265 & 0.001132 & & \\
\hline Total & 8 & 0.113670 & & & \\
\hline
\end{tabular}

Table 10. Comparison of actual and predicted values

\begin{tabular}{|l|l|l|}
\hline \multirow{2}{*}{} & \multicolumn{2}{|l|}{ Optimal Process parameters } \\
\cline { 2 - 3 } & Predicted & Experiment \\
\hline \multirow{2}{*}{ Level } & $\begin{array}{l}\text { Cutting Speed }=150 \mathrm{~m} / \\
\text { min, Feed }=0.2 \mathrm{~mm} / \mathrm{rev}, \\
\text { D.O.C }=0.5 \mathrm{~mm}\end{array}$ & $\begin{array}{l}\text { Cutting Speed }=150 \mathrm{~m} / \\
\text { min, Feed }=0.2 \mathrm{~mm} / \mathrm{rev}, \\
\text { D.O.C }=0.5 \mathrm{~mm}\end{array}$ \\
\hline Surface roughness $(\mu \mathrm{m})$ & 0.69 & 0.72 \\
\hline Interfacial temperature $\left({ }^{\circ} \mathrm{C}\right)$ & 154.14 & 157 \\
\hline Insert wear $(\mathrm{mm})$ & 0.259 & 0.29 \\
\hline
\end{tabular}

\section{Results and Discussion}

The result for the coated carbide obtained from the experiment is shown in Table 3.

For every one of the nine test runs, the responses like surface roughness, interfacial temperature and flank wear of the insert are analyzed. For each test three input parameters namely cutting speed, feed and depth of cut were considered.

These outcomes are evaluated with the Analysis of Variance (ANOVA), multiple regression analysis and grey relational analysis. The ANOVA determines the dominant input variable that has great impact on output responses. The correlation between the input and the output parameters were established by the multiple regression analysis. The optimal setting of the input parameters is determined by the Grey Relational Analysis.

\subsection{Analysis of Variance}

From ANOVA it can be found that which independent variable dominates the other variable. The ANOVA is carried out for a confidence level of $95 \% \mathrm{t}$. The measures are considered to be significant if the $\mathrm{p}$ values are less than 0.05 . The ANOVA results of the surface roughness, interfacial temperature and flank wear for the coated carbide is shown in Tables 4, 5 and 6.
From Table 4 it is found that for surface roughness the feed is the dominant variable followed by cutting speed and depth of cut. The value of R-sq for surface roughness is found to be $98.99 \%$.

For the interfacial temperature the cutting speed has a great impact followed by the depth of cut and the feed. The R-sq value for the interfacial temperature is found to be $99.98 \%$ and is shown in Table 5 .

In case of insert wear the three factors are considered to be insignificant where the cutting speed is the most influencing parameter followed by the feed and the depth of cut. The R-sq value for the insert wear is found to be 95.73\% and is shown in Table 6.

\subsection{Mathematical Modelling}

Surface Roughness $=0.639-0.002100$ Cutting Speed +1.317 Feed - 0.0016 D.O.C;

$(\mathrm{R}-\mathrm{Sq}=87.18 \%)$

Interfacial Temperature $=108.24$ + 0.4033 Cutting Speed - 6.7 Feed + 13.83 D.O.C;

$(\mathrm{R}-\mathrm{Sq}=97.04 \%)$

Insert Wear $=0.1328+0.001667$ Cutting Speed - 0.417 Feed + 0.0863 D.O.C;

$(\mathrm{R}-\mathrm{Sq}=85.42 \%)$

The value of R-Sq is found to be $87.18 \%$ for surface roughness, $97.04 \%$ for interfacial temperature and $85.42 \%$ 
for insert wear. The response predictions are better and a good relation is found between these variables.

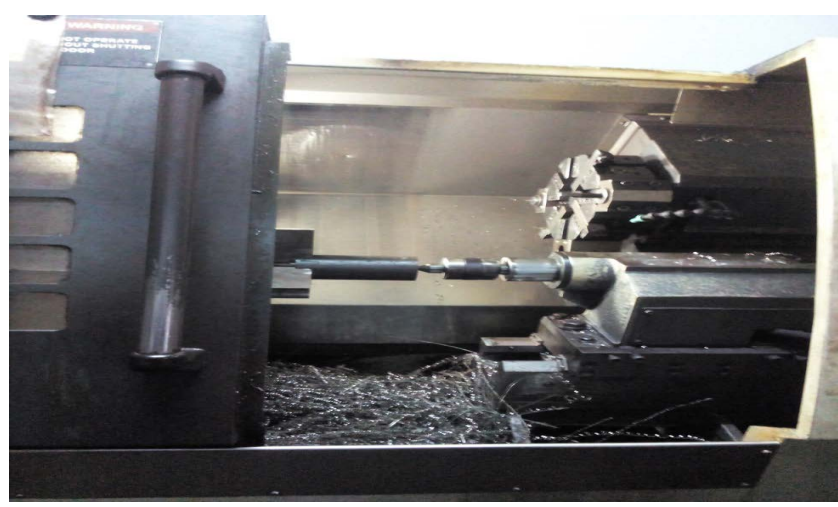

Figure 3. Dry machining of EN31 steel.

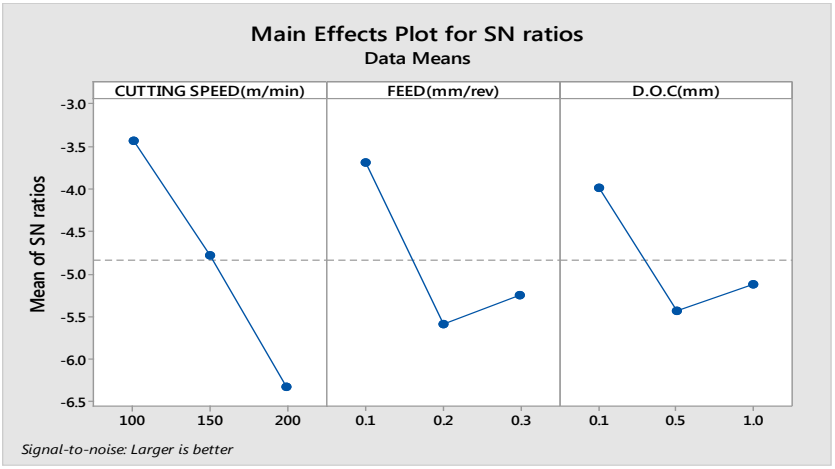

Figure 4. S/N Ratio graph for each parameter at different levels.

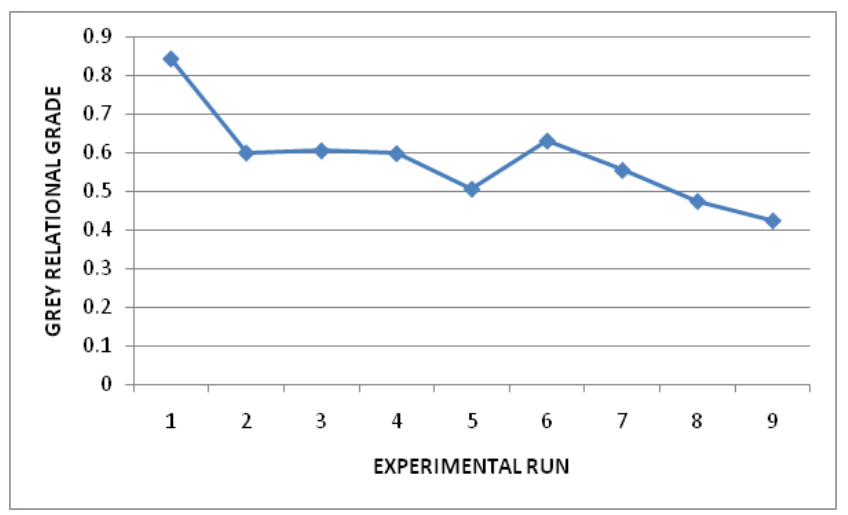

Figure 5. GRG for minimum surface roughness, minimum interfacial temperature and minimum insert wear.

\subsection{Multi-response Optimization with Grey Relational Grade}

The Grey relational coefficients and Grey relational grades for the coated carbide have been represented in Tables 7 and 8. The ANOVA of GRG with coated carbide is tabulated in Table 9.
From the ANOVA table it has been concluded that cutting speed is the most dominant parameter on Grey Relational Grade followed by feed and depth of cut. Figure 4 represents the main effect plot for $\mathrm{S} / \mathrm{N}$ ratios of GRG that shows the optimal settings of input parameters.

The optimal conditions according to Grey relational Taguchi approach has been found $100 \mathrm{~m} / \mathrm{min}$ cutting speed, $0.1 \mathrm{~mm} / \mathrm{rev}$ feed and $0.1 \mathrm{~mm}$ depth of cut. Figure 5 shows the Grey relational grades for minimum Surface Roughness, minimum Interface Temperature and minimum Insert Wear.

The confirmation tests were carried out for the optimal parameters with its levels and its characteristics were evaluated. Table 10 indicates the comparison between the experimental and the predicted values and a good agreement is found.

\section{Conclusions}

From this work the conclusions are summarized as follows:

- Coated carbides experience a lower surface roughness, lower interface temperature and lower flank wear.

- From the regression equation it is found that the R-Sq value is close to unity that indicates the good relation between the variables.

- Cutting speed is the most dominant parameter followed by feed rate and depth of cut.

- The optimal parametric combination is cutting speed $=100 \mathrm{~m} / \mathrm{min}$, feed $=0.1 \mathrm{~mm} / \mathrm{rev}$, depth of cut $=0.1 \mathrm{~mm}$.

- The performance of coated carbides is improved with the help of multilayer coating. As a result the surface roughness, interface temperature and flank wear are less when coated carbides are used instead of uncoated carbides.

\section{References}

1. Gaitonde VN, Karnik SR, Figueira L, Davim JP. Machinability investigations in hard turning of AISI D2 cold work tool steel with conventional and wiper ceramic inserts. International Journal of Refractory Metals and Hard Materials. 2009; 27(4):754-63. https://doi.org/10.1016/j. ijrmhm.2008.12.007

2. Das SR, Dhupal D, Kumar A. Experimental investigation into machinability of hardened AISI 4140 steel using 
TiN coated ceramic tool. Measurement. 2015; 62:108-26. https://doi.org/10.1016/j.measurement.2014.11.008

3. Bouacha K, Athmane M, Mabrouki T, Rigal J. Statistical analysis of surface roughness and cutting forces using response surface methodology in hard turning of AISI 52100 bearing steel with CBN tool. International Journal of Refractory Metals and Hard Materials. 2010; 28(3):349-61. https://doi.org/10.1016/j.ijrmhm.2009.11.011

4. Suresh R, Basavarajappa S, Gaitonde VN, Samuel GL. Machinability investigations on hardened AISI 4340 steel using coated carbide insert. International Journal of Refractory Metals and Hard Materials. 2012; 33:75-86. https://doi.org/10.1016/j.ijrmhm.2012.02.019

5. Pal A, Choudhury SK. Machinability assessment through experimental investigation during hard and soft turning of hardened steel. Procedia Materials Science. 2014; 6:80-91. https://doi.org/10.1016/j.mspro.2014.07.010

6. Suresh R, Basavarajappa S, Samuel GL. Some studies on hard turning of AISI 4340 steel using multilayer coated carbide tool. Measurement.1884; 45(7):1872-84. https://doi.org/10.1016/j.measurement.2012.03.024

7. Kumar A, Sahoo B. Performance studies of multilayer hard surface coatings ( $\mathrm{TiN} / \mathrm{TiCN} / \mathrm{Al}_{2} \mathrm{O}_{3} / \mathrm{TiN}$ ) of indexable carbide inserts in hard machining: Part-I (An experimental approach). Measurement. 2013; 46(8):2854-67. https://doi. org/10.1016/j.measurement.2013.03.024

8. Kumar R, Kumar A, Purna S, Mishra C. Comparative study on machinability improvement in hard turning using coated and uncoated carbide inserts: Part II modeling, multi-response optimization, tool life and economic aspects. Advances in Manufacturing. 2018; 6(2):155-75. https://doi.org/10.1007/s40436-018-0214-0

9. ChoudhurySK.Evaluation ofchip-toolinterfacetemperature: Effect of tool coating and cutting parameters during turning hardened AISI. Procedia Material Science. 2014;6:996-1005. https://doi.org/10.1016/j.mspro.2014.07.170

10. Chinchanikar S, Choudhury SK. Hard turning using HiPIMS-coated carbide tools: Wear behaviour under dry and Minimum Quantity Lubrication (MQL). Measurement. 2014; 55:536-48. https://doi.org/10.1016/j.measurement.2014.06.002

11. Valera HY, Bhavsar SN. Experimental investigation of surface roughness and power consumption in turning operation of EN 31 Alloy Steel. Procedia Technology. 2014; 14:528-34. https://doi.org/10.1016/j.protcy.2014.08.067

12. Abhang LB, Hameedullah M. Parametric investigation of turning process on en-31 steel. Procedia Materials Science. 2014; 6:1516-23. https://doi.org/10.1016/j. mspro.2014.07.132

13. Chen $\mathrm{X}, \mathrm{Xu}$ J, Xiao Q. Cutting performance and wear characteristics of $\mathrm{Ti}(\mathrm{C}, \mathrm{N})$-based cermet tool in machining hardened steel. International Journal of Refractory Metals and Hard Materials. 2015; 52:143-50.

14. Shalaby MA, El Hakim MA, Abdelhameed MM, Krzanowski JE, Veldhuis SC, Dosbaeva GK. Tribology international wear mechanisms of several cutting tool materials in hard turning of high carbon - chromium tool steel. Tribology International. 2014; 70:148-54. https://doi.org/10.1016/j.triboint.2013.10.011

15. Hessainia Z, Belbah A, Athmane M, Mabrouki T, Rigal J. On the prediction of surface roughness in the hard turning based on cutting parameters and tool vibrations. Measurement. 2013; 46(5):1671-81. https://doi. org/10.1016/j.measurement.2012.12.016

16. Rajabi A, Ghazali MJ, Junaidi S, Daud AR. Development and application of tool wear: A review of the characterization of tic-based cermets with different binders. Chemical Engineering Journal. 2014; 255:445-52. 